\title{
Variation in spring growth within white clover
}

J.R. CARADUS

DSIR G rasslands, Private Bag, Palmerston North

\begin{abstract}
In a spaced plant trial, plants of 27 cultivars in their second year of growth were undefoliated from late winter through spring and their growth rate determined relative to that of 'Grasslands Huia'. Variation between cultivars was large. Cultivars which had higher relative growth rates than Huia during this period included some small-leaved frost tolerant germplasm, although all of these had lower absolute growth scores than Huia. The second study measured proportion of clover, leaf size and stolon growing point densities of 27 white clover cultivars and breeding lines grown in mixed species grazed swards during late winter and spring in two successive years. Once again, variation between cultivars in spring performance relative to Huia was large. It was concluded that there is sufficient variation available within white clover for improvements in spring growth relative to Huia to be achieved by breeding. Nematode Resistant Pitau consistently had high growth rates relative to Huia in late winter and early spring, but this did not carry through into late spring. Cultivars and lines with better late winter growth than Huia had higher stolon growing point densities for their respective leaf sizes than poorer, later winter growers.
\end{abstract}

Keywords evaluation, mixed swards, spaced plants, later winter growth, stolon density

\section{Introduction}

White clover is grown in grazed mixed species swards to provide nitrogen, through nitrogen fixation, and to improve sward quality and hence animal performance. Recent studies have highlighted the importance of clover growth dynamics during spring in relation to annual production, long term persistence, and increasing nitrogen inputs into a grazed system. During spring individual white clover plant size declines and, correspondingly, plants that are unbranched increase, indicating a particular vulnerability to stress in spring (Hay et al. 1989). It has also been pointed out that increased clover growth in spring would be the most effective strategy for increasing annual nitrogen fixation rates (Crush 1989). However, clover growth rate is lower than that of most temperate grasses at the low temperatures common in early and mid-spring (Mitchell 1956). For these reasons studies have begun to determine the extent of variation between white clover cultivars and breeding lines for growth during late winter and spring when maximum temperatures are generally below $12^{\circ} \mathrm{C}$, i.e. temperatures at which temperate grasses would be assumed to have superior growth rates if temperature alone was the critical determining factor for growth,

\section{Materials and methods}

\section{Site details}

This study was conducted at DSIR Grasslands, Palmerston North. Mean daily minimum, maximum and grass minimum temperatures relevant to the spaced plant trial are given in Table la and for the mixed-species sward trial in Table $\mathrm{lb}$. While temperatures gradually increased throughout the duration of each trial, a large increase in grass minimum temperature-consistently occurred from mid-September onwards.

Table 1 Mean daily minimum, maximum and grass minimum temperatures during the measurement period of (a) the spaced plant trial and (b) the mixed-species sward trial.

\begin{tabular}{llccc}
\hline & & \multicolumn{3}{c}{ Temperature ${ }^{\circ} \mathbf{C}$} \\
\cline { 2 - 5 } Period & Maximum & Minimum & $\begin{array}{c}\text { Grass } \\
\text { minimum }\end{array}$ \\
\hline & & & $\mathbf{3 . 7}$ & $\mathbf{0 . 9}$ \\
(a) 20 June-18 Aug 1986 & 13.5 & $\mathbf{4 . 1}$ & 1.1 \\
19 Aug-1 Sept & $\mathbf{1 2 . 6}$ & $\mathbf{6 . 6}$ & $\mathbf{3 . 5}$ \\
2 Sept-18 Sept & $\mathbf{1 3 . 5}$ & $\mathbf{8 . 5}$ & $\mathbf{5 . 8}$ \\
19 Sept-9 Oct & 15.5 & $\mathbf{9 . 6}$ & $\mathbf{7 . 0}$ \\
10 Ott-29 Oct & $\mathbf{1 7 . 1}$ & $\mathbf{1 1 . 2}$ & $\mathbf{9 . 0}$ \\
30 Ott-29 Oct & $\mathbf{1 8 . 6}$ & $\mathbf{5 . 4}$ & $\mathbf{1 . 8}$ \\
(b) 7 July-19 Aug 1987 & $\mathbf{1 3 . 6}$ & $\mathbf{7 . 1}$ & $\mathbf{3 . 8}$ \\
20 Aug-22 Sept & $\mathbf{1 5 . 2}$ & $\mathbf{8 . 5}$ & $\mathbf{5 . 2}$ \\
23 Sept-27 Oct & 16.9 & $\mathbf{1 1 . 3}$ & $\mathbf{9 . 0}$ \\
28 Ott-3 Dec & $\mathbf{1 9 . 6}$ & $\mathbf{6 . 0}$ & $\mathbf{2 . 7}$ \\
3 June-9 Aug 1988 & 13.6 & $\mathbf{6 . 5}$ & $\mathbf{3 . 8}$ \\
10 Aug-15 Sept & $\mathbf{1 3 . 6}$ & $\mathbf{1 0 . 6}$ & $\mathbf{8 . 1}$ \\
$\mathbf{1 6}$ Sept-17 Oct & 16.9 & $\mathbf{9 . 3}$ & $\mathbf{6 . 9}$ \\
18 Ott-15 Nov & $\mathbf{1 7 . 8}$ & & \\
\hline
\end{tabular}


Table 2 Origin of white clover cultivars and breeding lines, their leaflet width, initial yield relative to Huia (at 18 Aug), leaf density $\left(\mathrm{no} / 100 \mathrm{~cm}^{2}\right)$ and slope of regression between growth relative to Huia and days from grazing, when grown as spaced plants.

\begin{tabular}{|c|c|c|c|c|c|c|c|}
\hline No. & $\begin{array}{l}\text { Cultivar (c) } \\
\text { or line }(1)\end{array}$ & Country of origin & $\begin{array}{c}\text { Leaflet } \\
\text { width }(\mathrm{mm})\end{array}$ & $\begin{array}{c}\text { Initial re } \\
\text { yield }\end{array}$ & $\begin{array}{l}\text { nitial leaf } \\
\text { density }\end{array}$ & $\begin{array}{l}\text { Slope } \\
\left(\times 10^{-3}\right)\end{array}$ & $\mathrm{P}$ \\
\hline 1 & S. $184(c)$ & U.K. & 7.3 & 0.87 & 58 & -1.37 & \#* \\
\hline 2 & Daeno $\mathbf{K}^{*}(\mathrm{c})$ & Denmark & 1.6 & 0.58 & 36 & 1.55 & *** \\
\hline 3 & Fries Groninger* (c) & Netherlands & 6.3 & 0.64 & 41 & 0.55 & ns \\
\hline 4 & Kopu (c) & N.Z. & 10.6 & 0.91 & 34 & -1.50 & $* * *$ \\
\hline 5 & $\mathbf{G} 23^{(1)}$ & N.Z. & 11.4 & 1.11 & 39 & -1.89 & \#草 \\
\hline 6 & Gomelskij* (c) & U.S.S.R. & 8.0 & 0.85 & 47 & -0.03 & $n s$ \\
\hline 1 & Pitau (c) & N.Z. & 11.0 & 1.10 & 41 & -3.44 & $* * *$ \\
\hline 8 & Tahora (c) & N.Z. & 6.7 & 0.83 & 56 & 0.26 & $\mathrm{~ns}$ \\
\hline 9 & Jogeva* (c) & U.S.S.R. & 8.3 & 0.76 & 38 & 0.70 & ns \\
\hline 10 & Lena* (c) & Sweden & 7.8 & 0.64 & 34 & 0.09 & $\mathrm{~ns}$ \\
\hline 11 & Makibashiro* (c) & Japan & 8.8 & 1.03 & 50 & -1.53 & ***** \\
\hline 12 & Menna (c) & U.K. & 8.4 & 0.80 & 44 & 0.07 & $n s$ \\
\hline 13 & Milkanova* (c) & Denmark & 1.2 & 0.74 & 38 & 0.54 & ns \\
\hline 14 & N.F.G. Gigant* (c) & Germany & 9.0 & 0.83 & 48 & -1.74 & **** \\
\hline 15 & Pilgrim* (c) & U.S.A. & 10.3 & 0.89 & 44 & -2.45 & $\neq * *$ \\
\hline 16 & Pertina* (c) & Netherlands & 1.1 & 0.88 & 55 & 0.44 & ns \\
\hline 17 & Podkowa* (c) & Poland & 8.0 & 0.71 & 41 & 0.83 & $*$ \\
\hline 18 & Radi* (c) & Poland & 9.0 & 1.03 & 47 & -3.11 & *\#* \\
\hline 19 & Retor* (c) & Netherlands & 1.9 & 0.66 & 44 & 0.01 & $\mathrm{~ns}$ \\
\hline 20 & Siwan (c) & U.K. & 8.7 & 0.98 & 47 & -1.10 & $\star$ \\
\hline 21 & Steinacher (c) & Germany & 7.1 & 0.79 & 52 & 0.10 & ns \\
\hline 22 & Undrom ${ }^{*}(\mathrm{c})$ & Sweden & 1.3 & 0.58 & 34 & 1.00 & \\
\hline 23 & Huia (c) & N.Z. & 8.4 & 1.00 & 48 & 0.00 & ns \\
\hline 24 & Isolation V (1) & N.Z. & 7.8 & 0.98 & 59 & 0.25 & ns \\
\hline 25 & ML-48-65* (c) & Canada & 7.1 & 0.68 & 42 & 1.43 & $* *$ \\
\hline \multirow{4}{*}{$\begin{array}{l}26 \\
21\end{array}$} & Southland sel $^{\mathbf{n}}$ (l) & N.Z. & 6.2 & 0.97 & 59 & -0.61 & $\mathrm{~ns}$ \\
\hline & Nematode Resistant & & & & & & \\
\hline & Pitau (l) & N.Z. & 12.8 & 1.22 & 39 & -0.89 & $\mathrm{~ns}$ \\
\hline & S.E.D. & & 0.6 & - & 7 & $m$ & - \\
\hline
\end{tabular}

*documented as being frost-hardy (refer Caradus 1986)

\section{Spaced plant trial}

Twenty-seven white clover cultivars and breeding lines that represented the range of morphological type and winter-hardiness were studied (Table 2).

Plants were planted at 60 -cm spacings in May 1985; there were 6 replicates of 5 plant rows of each cultivar arranged in a randomised block design. Plants were grazed by sheep in November 1985, January, March and June (20th) 1986.

Regrowth after grazing in June 1986 was visually scored using a O-10 scale on 18 August, 1 and 18 September, 9 and 29 October and 14 November, 1986. Leaf size and density of leaves (number per unit area) were measured on 28 August. Leaf size was determined by measuring the width of the middle leaflet of the second open leaf from the stolon tip and leaf density determined using a $88 \mathrm{~cm}^{2}$ quadrat which was thrown on to the plant and open leaves counted.

\section{Mixed species sward}

Plots $(50 \times 75 \mathrm{~cm})$ of 27 cultivars or breeding lines of white clover (Table 3 ) were planted in a perennial ryegrass sward. There were 30 plants per plot $(50 \mathrm{~cm}$ space between plots), which were arranged in a randomised block design with 4 replicates. The area was rotationally grazed by sheep 9 times per year, with the interval between grazing ranging from 24 days in spring to 60 days in winter. From late winter to late spring in each of years 2 and 3 the trial was 'grazed 4 times. Before each grazing, the proportion of clover in the sward and the stolon growing point density (Caradus et al. 1990) were measured. Leaf size was derived from number of leaves harvested and total leaf dry weight. Grazing times in year 2 were 19 August, 22 September, 27 October and 3 December, and in year 3,9 August, 15 September, 17 October and 15 November.

\section{Statistical analysis}

Growth scores from the spaced plant trial were standardised by dividing scores by the mean Huia score at each scoring. These relative score values were analysed by analysis of variance using a split-plot in time design; this determined whether cultivar growth scores increased, decreased or did not change significantly with time relative to Huia. The growth means of each cultivar relative to Huia were regressed linearly against time from grazing.

In the sward trial, proportion of clover was determined relative to that of Huia. Relative clover content was square root transformed to homogenise the variance before analysis of variance using a splitplot in time design. 
Table 3 Proportion of clover relative to Huia of cultivars and breeding lines grown in mixed species swards. Values are means of two-years and square root transformed. Asterisks indicate values that are significantly $(p<0.05)$ better than Huia.

\begin{tabular}{|c|c|c|c|c|}
\hline \multirow[b]{2}{*}{ Cultivar (c) or line (1) } & \multicolumn{4}{|c|}{ Harvest time } \\
\hline & $\begin{array}{l}\text { Late } \\
\text { winter }\end{array}$ & $\begin{array}{l}\text { Early } \\
\text { spring }\end{array}$ & $\begin{array}{l}\text { Mid- } \\
\text { spring }\end{array}$ & $\begin{array}{c}\text { Late } \\
\text { spring }\end{array}$ \\
\hline Crau (c) & $1.71^{\prime}$ & 1.43 & $1.57^{*}$ & $1.37^{*}$ \\
\hline $\mathrm{SC}-1$ (l) & 0.86 & 0.92 & 0.98 & 0.62 \\
\hline NZ x Algeria (I) & $1.58 *$ & 1.23 & 1.20 & 1.08 \\
\hline NZ x Morocco (I) & $1.86^{*}$ & 1.56 & 1.09 & 1.07 \\
\hline NZ x Spain (1) & 1.75 & 1.52 & 1.08 & 1.03 \\
\hline Ladino x Pitau (1) & 1.46 & 1.38 & 1.22 & 0.97 \\
\hline Pitau selection (l) & 1.33 & 1.73 & 0.47 & 0.49 \\
\hline \multicolumn{5}{|l|}{ Nematode Resistant } \\
\hline Pitau (1) & $1.87^{*}$ & $1.82^{*}$ & 1.23 & 1.18 \\
\hline NZ x Portugal (1) & 1.01 & 1.28 & 1.27 & 0.82 \\
\hline NZ x USA1 (1) & 1.29 & 1.15 & 0.95 & 0.84 \\
\hline NZ x USA2 (1) & 1.76 & $1.71^{*}$ & 1.31 & 1.34 \\
\hline NZ x Algeria 2 & 1.02 & 0.69 & 0.71 & 0.76 \\
\hline \multicolumn{5}{|l|}{ Root Knot } \\
\hline Nematode (1) & 0.54 & 0.75 & 0.84 & 0.51 \\
\hline G.39 (1) & 1.39 & $1.75^{*}$ & $1.60^{*}$ & 1.29 \\
\hline Southland ecotype (1) & 1.25 & 1.37 & 1.12 & 1.09 \\
\hline G.26 (1) & 1.21 & 1.86 & 1.39 & 1.24 \\
\hline Gene Pool 1 (I) & $1.93^{*}$ & 1.48 & 1.03 & 0.88 \\
\hline Gene Pool 2 (1) & 1.21 & 0.90 & 0.66 & 0.70 \\
\hline Gene Pool 3 (1) & $1.65^{*}$ & 1.55 & 1.13 & 0.89 \\
\hline Gene Pool 4 (1) & $1.72^{*}$ & $1.92^{*}$ & 1.46 & 1.22 \\
\hline Gene Pool 5 (1) & 1.56 & 1.39 & 1.30 & 0.99 \\
\hline Huia (c) & 0.97 & 0.98 & 0.93 & 0.96 \\
\hline Pitau (c) & $1.59^{*}$ & 1.49 & 1.45 & 1.01 \\
\hline Tahora (c) & 0.63 & 1.25 & 1.00 & 0.66 \\
\hline Kopu (c) & 1.31 & 0.87 & 0.70 & 0.64 \\
\hline G.23 (1) & 1.49 & $1.72^{*}$ & 1.30 & 1.15 \\
\hline NZ x USA (I) & $1.64^{*}$ & $1.63^{*}$ & 1.38 & 1.38 \\
\hline
\end{tabular}

SED between lines within harvest time 0,297

SED between harvest time within lines 0.223

\section{- Results}

\section{Spaced plant tria}

Regression analysis showed that 4 cultivars, Daena $\mathrm{K}$, Podkowa and Undrom, ML-48-65, had a significant increase in growth score relative to Huia with time (Table 2). Conversely, 9 cultivars, S.184, Kopu, G.23, Pitau, Makibashiro, N.F.G. Gigant, Pilgrim, Radi and Siwan, had significantly decreasing growth scores relative to Huia with time. The remaining 14 cultivars had a growth pattern, from late winter to late spring, not significantly different from-that of Huia.

Slope of the regression (relative growth versus time) was negatively $(p<0.01)$ correlated with both leaf size $(\mathrm{r}=-0.54)$ and initial relative growth at 18 August $(\mathrm{r}=\boldsymbol{m}$ 0.71). Growth of large-leaved cultivars decreased with time relative to Huia, whereas for medium and small-leaved cultivars growth relative to Huia did not vary significantly with time. Regressions of growth relative to $\mathrm{Huia}^{(\boldsymbol{y})}$ against days from grazing" were $\mathrm{y}=1.11-0.00198 x\left({ }^{* *}\right), y=$ $0.90-0.00015 x(n s)$ and $y=0.75+0.00036 x(n s)$, respectively. Leaf size and initial relative growth were positively correlated $(r=+0.68, p<0.01)$.
The largest changes in temperature occurred between the periods ending 18 September and beginning 19 September, with a $2^{\circ}, 1.9^{\prime \prime}$ and 2.3" increase in maximum daily temperature, minimum daily temperature and grass minimum temperature respectively (Table la). Data for growth relative to Huia were re-examined for significant increases and decreases before and after the 19 September. For 17 cultivars, there was no significant change in relative growth either before or after the 19 September. For Daeno, Fries Groninger, Jogeva, Pertina and Undrom, there was no significant change in relative growth before 19 September but a significant increase after 19 September. For Pitau, NGF Gigant and Radi, there was a significant change after 19 September, For Nematode Resistant Pitau and Tahora, there was a significant increase in relative growth before 19 September, but after 19 September Nematode Resistant Pitau had a significant drop in relative growth whereas for Tahora there was no significant change.

'Frost-sensitive' cultivars had decreasing growth relative to Huia from later winter to late spring, whereas for 'frost tolerant' cultivars, growth relative to Huia did not change significantly. Regression of growth relative to $\mathrm{Huia}^{(\boldsymbol{y})}$ against days from grazing $^{(\boldsymbol{x})}$ were $y+1.03-0.00083 \mathrm{x}(*)$ and $y=0.77-$ $0.00015 x(n s)$, respectively. However, the leaf size of 'frost tolerant' cultivars had a significant effect on change in growth relative to Huia with time. Largeleaved 'frost tolerant' cultivars had a significant decrease and small-leaved cultivars a significant increase in growth relative to Huia from late winter to late spring. There was no significant change in growth relative to Huia for-medium-leaved cultivars. Regressions of growth reiative to $\mathrm{Huia}^{\left({ }^{(y)}\right.}$ against days from grazing" were $y=0.66+0.00058 x(*), y=$ $1.05=0.0024 x(* *)$ and $y=0.83+0.000005 x(n s)$, respectively.

\section{Sward trial}

There was a significant $(p<0.05)$ line $x$ harvest time interaction for proportion of clover in the sward relative to Huia but no significant year $x$ line $x$ harvest time interaction. Proportion of clover- for all lines either significantly decreased or remained the same relative to Huia from late-winter to late spring. However, a number of lines had a significantly higher proportion of clover in the sward than Huia in late winter and early spring (Table 3 ). The most notable of these were Nematode Resistant Pitau, NZ $\mathrm{x}$ USA2 and Gene Pool 4. In late winter 11 cultivars and breeding lines had a significantly higher proportion of clover in the sward than Huia (Table 3 ). No lines had a significantly lower proportion of clover in swards than Huia at any time. The largerleaved lines with good late winter growth '(Table 3) had as a group higher stolon growing point densities for their respective leaf sizes than lines with late winter growth similar to that of Huia (Figure 1). 


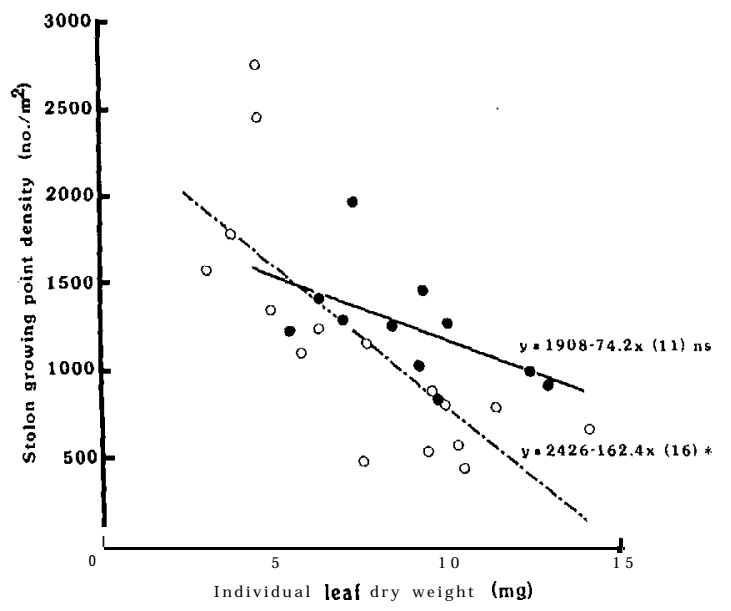

Figure 1 Comparison of relationship between leaf size and stolon growing point density of white clover cultivars and lines with good late winter growth (O) and cultivars and lines with late winter growth similar to that of Huia (O) Slopes of regression were significantly different $(p<0.05)$.

\section{Discussion}

The aim of the present study was to identify cultivars or breeding lines of white clover which had growth rates that increased during spring at a relatively greater rate than that of Huia. Early spring (up until mid-September) was of particular interest, since this was the time when temperatures would tend to favour grass growth rather than clover growth. Few cultivars and lines were common to both trials. However, Nematode Resistant Pitau was, and it consistently had greater late winter and early spring growth than did Huia. The high early spring growth of Tahora relative to that of Huia observed in spaced plants was not observed in the sward trial where other lines with high early spring growth included NZ $\mathrm{x}$ USA2 and Gene Pool 4. These are both largeleaved types similar to Nematode Resistant Pitau.

The small-leaved 'frost tolerant' cultivars, examined only in spaced plants, had as a group significantly greater growth rates relative to Huia throughout the trial, but from analysis of variance data the increases were greatest in late rather than early spring.

Cultivars with Mediterranean parentage exhibit better cool-season growth (autumn/winter) than cultivars from northern Europe, which in turn are more frost hardy (reviewed by Williams 1987). Growth relative to Huia in late winter (mid-August) was highest in the spaced plant trial for Nematode Resistant Pitau, G.23 and Pitau, and in the sward trial for Gene Pool 1, Nematode Resistant Pitau, NZ $x$ Morocco, NZ x USA2, NZ x Spain, Gene Pool 4, Crau, Gene Pool 3, NZ x USA3, Pitau and NZ x Algeria, All of these are large-leaved types and all except the NZ $x$. USA lines have known mediterranean parentage. Sufficient genetic variation does exist for improvements in early spring growth relative to Huia to be achieved by breeding.
Key factors that may be related to enhanced early spring growth of white clover may include the ability to maintain a strong stolon base during winter (Harris et al. 1983), an upright habit (Eagles \& Othman 1986) to compete with grass growth, an ability to respond to increasing day length and total radiation (Eagle \& Othman 1986), and an ability to grow at low temperatures (Ollenshaw 1983). Cultivars and lines with improved late winter growth did have higher stolon growing point densities than other lines of comparable leaf size (Fig. 1). These 'improved' lines, however, did not have significantly greater leaf sizes in late winter and (hence more upright habit, since leaf size and habit are strongly correlated - Woodfield \& Caradus 1990) than other lines examined. While most of the improved latewinter growers had Mediterranean parentage, many of the poorer lines also had Mediterranean parentage, suggesting that the origin of lines and concomitant differences in response to changes in day length and total radiation may not be the critical factors affecting late winter and early-spring growth. Further studies will be needed to determine whether an ability to grow at low temperatures is related to late winter and early spring growth.

\section{REFERENCES}

Caradus, J.R. 1986. World checklist of white clover varieties. NZ journal of experimental agriculture 14: 119-164.

Caradus, J.R.; Woodfield, D.R.; van den Bosch, J.; MacKay, A.C.: Wewala, S. 1990. Seasonal variation in stolon growing point density of a world collection of white clover (Trifolium repens L.) cultivars. $N Z$ journa of agricultural research 32: 453459.

Crush, J.R. 1989. Legume breeding strategy for increased nitrogen fixation in New Zealand temperate pastures. Proceedings XVI International Grassland Congress: $125-126$.

Eagles, C.F.; Othman, O.B. 1986. Effect of temperature, irradiance and photoperiod on morphological characters of seedlings of contrastine white clover oovolations. Annal of applied biology 108: 629-638.

Harris, W.; Rhodes, I.: Mee, S.S. 1983. Observations on environmental and genotypic influences on the overwintering of white clover. Journal of applied ecology 20: 609-624.

Hay, M.J.M.; Brock, J.; Thomas, V.J. 1989. Characteristics of individual white clover plants in grazed swards. Proceedings XVI Internationa Grassland Congress: 1051-1052.

Mitchell, K.J. 1956. The influence of light and temperature on the growth of pasture species. Proceedings VII International Grassland Congress: 58-69.

Ollerenshaw, J.H. 1983. Genetic variation in yield components of Trifolium repens at low temperature. pp 89-101, In D.G. Jones and D.R. Davies (eds) Temperature legumes. Physiology, genetics and nodulation

Williams, W.M. 1987. Adaptive variation. pp. 299-321, In Baker., M.J.; Williams. W.M. (eds). White clover. CAB International

Woodfield, D.R.; Caradus, J.R. 1990. Estimates of heritability for, and relationships between, root and shoot characters of white clover. II. Regression of progeny on mid-parent. Euphytica 46: 211-215. 